LETTERS TO THE EDITOR.

[The Editor does not hold himself responsible for opinions expressed by his correspondents. Neither can he undertake to return, or to correspond with the writers of rejected manuscripts intended for this or any other part of NATURE. No notice is taken of anonymous communications.]

\section{The Austro-Hungarian Map of Franz Josef Land.}

In common with all who take an interest in Arctic research, I was very much surprised to learn, on the return of the $W i n d$ ward, last year, that the Jackson-Hamsworth polar expedition had detected, what seemed to them, extraordinary inaccuracies in Payer's map of Franz Josef Land. Finding, however, that Mr. Jackson's sledge journeys had only been directed along the very outskirts of the region laid down by Lieut. Payer, I came to the conclusion that the discrepancies pointed out were no greater than might be expected in a part of the map, where the Austrian explorer had obviously meant rather to indicate the presence of some geographical feature, than to give its exact position. I also hoped that Mr. Jackson's persevering endeavours would eventually lead him to some point where he could effect a satisfactory juncture of his own survey with that of his predecessor.

When, however, on August I3 last; I had the great pleasure of meeting Dr. Nansen at Vardö, a few hours after he had landed from the Windward, I was absolutely astounded when he informed me, with evident distress, that the northern part of the well-known map of Austria Sound was utterly wrong. Indeed the circumstantial and graphic telegrams, which at that moment were being flashed round the whole globe, told how Dr. Nansen and Lieut. Johansen, on their unparalleled return journey, had failed to identify a single geographical feature dis. covered by the intrepid Austrian explorer; how, on the contrary, they had, on August 6, I895, found three snow-covered islands in $81^{\circ} 38^{\prime} \mathrm{N}$. lat. and about $63^{\circ} \mathrm{E}$. long., and how the afterwards slowly worked their way to their winter quarters in $81^{\circ} \mathrm{I}^{\prime} \mathrm{N}$. lat. and $56^{\circ} \mathrm{E}$. long.; thus, to all appearance, actually crossing Payer's sledge tracks without finding any agreemen with his map. The three islands just mentioned would, according to Dr. Nansen's determination, come in the very middle of Lient. Payer's Dove Glacier. The publication of Dr. Nansen's book can alone enable geographers to decide as to the relative positions that Austria Sound and the three islands of the Norwegian explorers have to occupy on the map.

Respecting the accuracy of the southern part of Lieut. Payer's map, there can be no doubt whatever ; for if we turn to the thir section of the "Denkschriften der Kaiserlichen Akademie de Wissenschaften," Band xxxv, Vienna, I878,1 we shall find from Weyprecht's paper on the astronomical and geodetic results of the Austro-Hungarian Arctic expedition, that the latitudes and longitudes of the Teretthoff in the land ice, and of certain points on the neighbouring coast, notably Cape Tegetthoff and the western extremity of Wilczek Island, have all the precision that could be obtained from a long series of meridian altitudes, and no less than 2 I 8 lunar distances, combined with a systematic triangulation. This triangulation was connected with all the neighbouring islands within a distance of some 30 or 40 miles. The satisfactory character of this part of the map was proved by Mr. Leigh Smith, who, during his first voyage to Franz Josef Land, passed close under Cape Teget thoff and the south-western shore of Wilczek Island, where he saw, but did not visit, the large cairn in which the Austrian explorers placed a number of documents and a minimum thermometer. (See "Denkschriften," l.c., p. 67, where the late Lieut. Weyprecht placed on record directions for opening the cairn without moving the thermometer from its horizontal position, and thus sacrificing the valuable indication it may yet afford.)

Naturally the survey grew less accurate when it came to be extended up Austria Sound; but even there the latitudes, at least, must be very near the truth, as they are founded on numerous meridian altitudes of the sun. Fortunately an observation was secured in $81^{\circ} 57^{\prime} \mathrm{N}$. lat. within a few miles of the most northern point reached. Hence there is no reason whatever to

I This volume is devoted exclusively to the scientific results of the ex pedition under Paver and Weyprecht.

2 Near the poles linar distances define the observer's position much more accurately than in lower latitude; not only because the degrees of longitud are less, but also on account of the imaller parallax in right ascension. It is therefore earnestly to be desired that explorers on boat or sledge journeys should avail themselves of this invaluable method. doubt that Iieut. Payer and his two companions, Midshipman Orel and the seaman Zaninovich, attained the latitude of $82^{\circ} 5^{\prime}$, as detailed in the document now lying in a bottle on the summit of Cape Fligely. Unfortunately there is not the same certainty with regard to the longitudes, at least in the northern part of the map, as they rest solely on compass azimuths or bearings taken with the theodolite, often observed under very unfavourable conditions. (See Payer's "New Lands within the Arctic Circle," vol. ii. p. 77.) Had circumstances permitted the astronomical determination of a single longitude near the northern limit of the survey, no uncertainty as to the position of even the remoter parts of Austria Sound could have arisen. In conclusion, it may be mentioned that Lieut. Payer has deposited with the Royal Geographical Society all the materials used in the construction of his map; it is quite possible that a careful revision of these papers may remove the remaining uncertainty which, at present, hangs over the position of the northern part of the land which my old comrade explored in the face of so many difficulties.

Royal Observatory, Edinburgh, November 6. RALPH COPELAND.

\section{The Inheritance of Specific Characters.}

Prof. Meldola (Nature, October 22, p. 594), referring to the increasing breadth of carapace in growing crabs, suggests as an alternative to selection acting during the present life of the individuals, that "breadth of carapace.. . had a selection value in the phylogeny; now this character appears at a late stage in the ontogeny." Before accepting this interesting sug. gestion as plausible, one would like to hear, from Prof. Meldola or any one else, of other instances in which a character that has been of selection value "in the past history of the species" does not appear until a late stage in the present individual history. My own knowledge does not extend further than the fact that such characters tend to be inherited at an earlier stage; of their inheritance at a later stage, I know no instances. Were this a universal principle, the selection of broader carapaced individuals must have taken place not very long ago, the conditions can hardly have been very different to now, and, as now, the character must have appeared at a late state in the ontogeny ; in short; Prof. Meldola's alternative would only shift the need for an explanation a little distance back. The principle, however, may not be so general in its application as many of us have been led to believe. But, since in zoological speculation an hypothesis should. be proved consonant wlth some known fact, Prof Meldola may fairly be asked to adduce facts in harmony with the idea which he states he has always entertained.

Since your report of the discussion on Neo-Lamarckism in Section $\mathrm{D}$ at the British Association meeting will doubtless be regarded as authoritative, may I take this opportunity of correcting the sentence, "Mr. F. A. Bather thought the Ammonites afforded at least some proof of the Neo-Lamarckian doctrine." He may have "thought" so, though I greatly doubt it, but he certainly did not say so. He was using the Ammonites as an example, to ask Prof. Lloyd Morgan how a modification of the senile parent could affect the limits of variation in its offspring, most of which had already been produced ; or how modification even of the adult could affect the limits of variation in its offspring, which do not present the character of the assumed modification until they themselves become adult. The point of these questions would be more obvious to your readers, had your report alluded to the thesis that I imagined to constitute Prof. Lloyd Morgan's main contribution to the discussion.

\section{F. A. BATHER.}

Is the first place, I will take the opportunity afforded me by Mr. Bather, of correcting a slip in my letter; it is narrowness of carapace that is being, or has been, selected, and not breadth, as I stated. This, however, in no way affects the suggestion. In the next place, I must part company from Mr. Bather on a point of fundamental principle. I decline to accept, as a canon of scientific method, that a zoological (why particularly "zoological"?) hypothesis put forward in explanation of a body of facts still under investigation, and, possibly, leading us on to new principles, should, in order to become plausible, "be proved consonant with some known fact." I take it that, in making tentative suggestions for the interpretation of results obtained by observation, as in the case under consideration, it is sufficient, if the hypothesis is not opposed by any known fact. I did not lay it down as a dogma that selection must have acted in the way

NO. I 4 I I, VOL. 55] 